\title{
Progress and Impact of LEAP: An NSF S-STEM Scholarship Project
}

\section{Dr. Afsaneh Minaie, Utah Valley University}

Afsaneh Minaie is a professor of Computer Engineering at Utah Valley University. She received her B.S., M.S., and Ph.D. all in Electrical Engineering from University of Oklahoma. Her research interests include gender issues in the academic sciences and engineering fields, Embedded Systems Design, Mobile Computing, Wireless Sensor Networks, Nanotechnology, Data Mining and Databases.

\section{Dr. Reza Sanati-Mehrizy, Utah Valley University}

Reza Sanati-Mehrizy is a professor of Computer Science Department at Utah Valley University, Orem, Utah. He received his M.S. and Ph.D. in Computer Science from the University of Oklahoma, Norman, Oklahoma. His research focuses on diverse areas such as: Database Design, Data Structures, Artificial Intelligence, Robotics, Computer Aided Manufacturing, Data Mining, Data Warehousing, and Machine Learning. 


\title{
Progress and Impact of LEAP: An NSF S-STEM Scholarship Project
}

\begin{abstract}
Utah Valley University was awarded an NSF S-STEM grant for $\$ 600,000$ (over a five-year period) to improve outcomes for students in computer science and engineering through Leadership, Engagement, Academic Mentoring, and Preparation (LEAP). This paper presents the progress and impact of this scholarship program on the institution, its computer science program, and the community.
\end{abstract}

\section{Introduction}

Utah Valley University (UVU) is a comprehensive regional university with over 32000 students charged with serving Utah county, which is the second largest county in the state. As a large, open-enrollment, public university, UVU has the highest proportion of low income students in the state of $\mathrm{Utah}^{10}$. Around $35 \%$ of students are classified as non-traditional students (age 25 or older). Many students have families, and nineteen percent of UVU students have children under the age of five ${ }^{1}$. UVU's students live at home or in off-campus housing, which makes it very difficult to organize activities for them. Many students do not have time to spend much time outside of class on campus, leading some to feel little connection with other students. About $80 \%$ of UVU's students will remain in their communities and pursue employment in this region $^{2,6}$.

Utah County has been one of the fastest growing regions in the country with more than $96 \%$ growth between 1990 and 2010 time period $^{11}$. Because of this rapid growth, UVU has undergone multiple transitions since its origin in 1941 and has expanded its mission and role within the region. In 1987, it was a community college. The institution became a state college in 1993 and a regional university in 2008. In fall 1993, the enrollment was 10,500 and tripled in fall 2012 to 31,500 . "The demand for education has been met by an increase in baccalaureate degrees offered from three in 1995 to 66 in 2012 in addition to three masters programs as well as 64 associate's degrees. This required institutional transition has strained state and community resources and created a number of challenges, particularly in the availability of scholarship funds" $"$.

\section{Computer Science Department}

The Computer Science department at UVU offers a Bachelor's Degree in Computer Science with two areas of specialization - Computer Science (traditional) and Computer Networking. It also offers a Software Engineering degree as well as a Computer Engineering degree. The Bachelor of Science in Computer Science program was one of the original Bachelor of Science programs implemented at UVU in 1993. The program's goal has been to provide a quality program that meets accreditation standards while providing the students with a skill set that allows them to succeed in computing careers. The curriculum content for the Computer Science degree is based on the 2008 ACM Curriculum Report. The Computer Science degree at UVU is accredited by Accreditation Board for Engineering and Technology (ABET) in 2002 and currently has more than 850 students. The program also has an advisory board comprised of representatives of local 
industry who assist in aligning the program to industry needs and helping to acquire industry support and resources.

Table 1 and 2 shows the enrollment and graduation trends in the Computer Science program. As can be seen from the tables, the number of students has continued to rise over the past five years, however the graduation rate remains low. Many students, particularly juniors and seniors, work over 20 hours a week to support their families while attending school, thus slowing down their progress and delaying their graduation. The majority of our students are married and have several children. These students often leave their programs of study early to accept employment in an industry anxious for employees. The Utah Department of Workforce job forecasts and other job trends surveys indicate that while these students can earn strong salaries without degrees, their careers will not advance as they would with degrees ${ }^{3,6}$. Employers are also feeling the disadvantage of too few job candidates with the adequate training provided by a baccalaureate degree ${ }^{4,6}$. The lack of adequate number of scholarships in Computer Science and Engineering programs is a significant inhibitor in graduating and enrolling more students.

\begin{tabular}{|c|c|c|c|c|c|}
\hline \multirow[t]{2}{*}{ Degree Program } & \multicolumn{5}{|c|}{ Fall Enrollment } \\
\hline & 2011 & 2012 & 2013 & 2014 & 2015 \\
\hline Computer Science & 583 & 631 & 684 & 775 & 885 \\
\hline $\begin{array}{l}\text { Software } \\
\text { Engineering }\end{array}$ & 76 & 72 & 92 & 109 & 114 \\
\hline $\begin{array}{l}\text { Computer } \\
\text { Engineering }\end{array}$ & & 60 & 105 & 143 & 153 \\
\hline
\end{tabular}

Table 1: Enrollment in Computer Science Department

\begin{tabular}{llllll|}
$\begin{array}{l}\text { Computer } \\
\begin{array}{l}\text { Science } \\
\text { Department }\end{array}\end{array}$ & 2011 & 2102 & 2013 & 2014 & 2015 \\
\hline B.S. & 33 & 27 & 39 & 42 & 49 \\
\hline Associate & 6 & 2 & & 12 & 13 \\
\hline Certificate & & & 1 & 3 & 12 \\
\hline
\end{tabular}

Table 2: Graduation in Computer Science Department

\section{LEAP Project Goal and Objectives}

The goal of the LEAP project is to increase the graduation rate for students in Computer Science and Engineering programs at UVU, which is an open enrollment university, and to better prepare them for continued education and/or success in the STEM workforce. This is accomplished by providing scholarships to academically talented students with financial need and by providing leadership training and opportunities, engaged learning activities, and mentorship (both studentto-student and faculty-to-student) ${ }^{6}$.

The objectives of the NSF LEAP project are to: 
1. "Increase support of financially needy, but academically talented students (including students from underrepresented groups) with an interest and aptitude for computer science and engineering degree programs by offering an average of 21 scholarships per year over a four-year period.

2. Increase the graduation rates of participating students in Computer Science and Engineering.

3. Provide leadership training and opportunities for students within a student chapter of a professional organization, through multidisciplinary projects, and through student-tostudent mentoring.

4. Strengthen engaged learning opportunities for students through a CS 1400 (Fundamentals of Programming) course project (freshman level) and through multidisciplinary IEEE student chapter projects \& a required for-credit capstone project.

5. Provide faculty mentors for each program participant; increase the efficacy of faculty mentoring provided to each student participant in the scholarship program by facultymentor training and accountability.

6. Establish mechanisms for acquiring ongoing sources of funds to sustain at least five annual full-tuition scholarships after the grant is over."6

The LEAP program addresses the three following areas ${ }^{6}$ :

1) The financial and educational needs of students in computer science and engineering disciplines at an open enrollment university.

2) Increases leadership opportunities for students to better prepare them for their professions and advanced education

3) The needs of the regional workforce ${ }^{6}$.

At many institutions of higher education, 50 percent or more of the freshman computer science and engineering students fail to complete their programs due to a variety of reasons. Many computer science and engineering programs are trying to identify these reasons and find a solution to remedy it. A common goal among most of the educators in freshman engineering programs is to generate strategies designed to improve the success of first-year engineering students. Since fewer students are entering computer science and engineering programs, it is essential that greater effort and attention be given to retaining students who have decided to pursue a computer science and engineering education.

Retention of computer science and engineering students is a major problem at many institutions of higher education. Retention issues have a big impact on the colleges and universities in a variety of areas such as academic affairs, student services, and even recruitment of new engineering students. Nowadays, graduation rates are published and lower rates reflect poorly on an institution of higher education. Because of these reasons and more, colleges and universities have turned their attentions to finding new ways to retain the students that do enroll in their computer science and engineering programs.

In order to increase the retention rate of our Computer Science, Computer Engineering, and PreEngineering programs, a survey was developed for previous students in CS 1400 (Fundamentals of Programming) course, which has a failure rate of more than $50 \%$. The Fundamentals of 
Programming course is a required course for all the above three programs. In February 2015, Utah Valley University's office of Institutional Research and Information conducted this survey of a large sample of previous CS 1400 students, dating back to 2007. A total of 3,464 students were invited to participate, and 362 students completed the survey (10.5\%).

The result of the survey is as follows: Seventy-three percent of the students said that computers are a hobby of theirs. Sixty-nine percent of the students did not take any programming classes in high school. While enrolled in CS 1400, 68\% of the students attended the class more than 95\% of the time. Sixty-one percent of the students spend between 4 to 10 hours per week outside of class working on projects and preparing for exams. Seventy-four percent of students were working while taking the course. Forty-six percent of the students were working more than 30 hours per week and 57\% of the student's work was unrelated to computer science. Only $13 \%$ of the students said that the class size was too large. Fifth two percent of the students were unaware of the fact that tutoring was available for this class. Fifty-one percent of students received help from friends or family for this class. Eighty-three percent of the friend/family who helped the students worked in a computer science related field. Fifty-six percent of the students said that the class size was adequate. Fifty-two percent of the students were not aware of the fact that tutoring is available for this course. Eighty-seven percent of the students did not meet with a tutor. Forty percent of students that received tutoring said that tutoring was very helpful. Fiftynine percent of the students never met with their professor during their office hours. Forty-one percent of the students who met their professors during their office hours said that these meeting were very helpful. Forty-one percent of the students who did not meet with their professor said that they did not have time to meet their professor. Fifty-six percent of the students are financing their own higher-education.

In order to increase the retention rate of students in this introduction to programming course, the following actions are recommended as the result of our first course in programming (CS 1400) student survey:

- Place strong teachers in this introductory course.

- Providing well-publicized tutoring for the course.

- Increase the tutoring hours.

- Select a better textbook for the course.

- Provide financial assistant to the students so that they don't have to work as much.

- Hold at least one class per week in lab.

- Change the course's language to $\mathrm{C}++$ so that they learn the same language in both of the introductory level programming courses. At this writing, $\mathrm{C \#}$ is the language that is taught in the first course and $\mathrm{C}++$ in the second course of our introductory programming courses.

Literature review has also shown that the retention rate tends to increase if the students are involved early with both faculty and peers in the academic and social systems of the university. 6,7 By enhancing student-to- student and student -to-faculty interactions increases the retention rate. These interactions are most effective if they occur within the first semester of the college experience ${ }^{9}$. 


\section{LEAP Project Management Plan}

As part of the LEAP grant application to the NSF, UVU developed a project management plan for the S-STEM scholarship program. Specifically, the PI has the overall administrative responsibility for the project and for interacting with NSF. She coordinates the activities of the Project Management Team, including such activities as advertising and recruitment of students, selection of students, maintenance of LEAP records, and oversight of student support services. She has the fiscal oversight and reporting responsibilities for the project. Co-PI's are responsible for conducting selection of scholarship recipients, ensuring that recipients understand their obligations to the program, assigning mentors, meeting with students regularly, and monitoring their progress.

\section{Selection Criteria}

Students are selected based on the following:

1) U.S. Citizen or Permanent Resident.

2) Must be admitted in a four-year Computer Science program at UVU or a two years Pre-Engineering program at UVU with the plan to transfer into an Engineering four-year program.

3) Demonstration of financial need in accordance with the U.S. Department of Education rules for Federal financial aid.

4) Full-time student majoring in Computer Science, Computer Engineering, Software Engineering, or Pre-engineering 6 .

\section{Student Agreement}

The selected students will commit to progressing in their major by signing a contract between the student and the institution/department. This contract will set out their requirements to accomplish the following ${ }^{6}$ :

1) Maintain a grade point average of at least 3.0 in all classes taken.

2) Meet with their faculty mentor monthly.

3) Meet with their academic advisor at least once each semester to plan their program coursework, assess the need for tutoring or other services, plan graduate school application or employment strategy, and/or receive referrals to other campus resources.

4) Attend $80 \%$ of the monthly LEAP meetings.

5) Participate in the IEEE Student Chapter and CE Club; participants will be encouraged to accept a leadership role as they become available.

6) Where possible, return service to the program or the community, in the form of tutoring, service learning, mentoring, visits to high school classrooms, or other activity (not required).

7) Compile a portfolio of work that includes a short annual report to the faculty mentor that outlines the year's goals and accomplishments. (Students' required out-of-class time commitments will not be extensive and will focus on the most important activities for program coherence and student success.) The most important element of the student 
contract is the student's academic performance; there may be some flexibility in evaluating the student's eligibility to continue in regards to other contract elements ${ }^{6}$.

\section{Major Engagement Activities}

Currently, the LEAP program is in its second year since induction. One of the goals of this project is to increase the retention rate of the students in the computer science and engineering programs by providing engaged learning opportunities and enrichment activities. The scholarship recipients are participating in interdisciplinary engaged learning opportunities through the Computer Engineering club and IEEE student chapter projects, a required for-credit capstone project, and optional internships and faculty mentored research. Enrichment activities include leadership training and opportunities, monthly LEAP participant meetings, involvement in student professional organizations or other student service organizations, field trips, networking opportunities, and faculty mentoring.

The main activities of the first year were to create the LEAP Scholarship Program at the computer science department at UVU. The process for selecting LEAP scholars was generated and advertisement materials were distributed for the program. Recruitment activities were conducted at both UVU and the local high schools. A flyer was created that was taken to the high schools by the UVU's office of Future Students to recruit students to the LEAP Program. The flyer was also distributed to the current students at the university, in order to recruit current undecided students to the LEAP Program. Applications for scholarships were received through UVU's Scholarship Office's website. The applications were reviewed by the PI and Co-PIs. 13 scholarships were awarded for the fall and 14 scholarships spring of 2015.

In order to retain our scholars in the LEAP programs, a survey was developed for previous students in CS 1400 (Fundamentals of Programming) course which has a failure rate of more than $50 \%$ and was analyzed to find how to retain the students better in that course. The following activities were provided for the LEAP scholarship recipient during the fall of 2015 semester:

- NSF LEAP Program Meet Your Faculty Mentor Night - In this activity each scholarship recipient was assigned a faculty advisor. There are two organizations that the computer science and engineering students are active. These two organizations are Computer Engineering Club (CE club) and the UVU's IEEE Student Chapter. During the Meet Your Faculty Mentor Night, the election for six officers for each organization was done and twelve of the LEAP scholars filled these positions. This is a great opportunity for the LEAP scholarship recipient to get leadership experience.

- Field trip to Hill Air Force Base which is one of the employers of our graduates.

- MATLAB Workshop led by the MathWorks Company.

- Two Arduino Workshops led by other students. One workshop was on introduction to Arduino and the other one was on interfacing Arduino with MATLAB. Both of these workshops were taught by the NSF LEAP scholars.

- Scholarship recipient participated in Fall Club Rush activities. 
At the time of this manuscript, for the spring 2016 semester, two speaker events are scheduled through the CE club and UVU's IEEE chapter. Two of the student's scholars are serving as the President of the CE club and UVU IEEE Student Chapter. These students organized the two speaker events. These talks are given by two new faculties in our department on their research topic. Two of the scholars are serving as tutors for the program. We are in the process of purchasing trainer boards and kits for the students to work on team projects in the IEEE Student Chapter. They also participated in Spring Club Rush activities.

\section{Demographics}

Table 3 provides information on the number of scholarships given and the demographics of scholars. In the second year of the LEAP project, 13 scholarships were awarded for Fall and 14 scholarships for Spring semesters. As can be seen from the table 3, there are total of $8(57 \%)$ non-traditional students who are benefitting from this program during Spring 2016. These students are older students who are returning after an absence from education. Non-traditional students usually have families that need to support. There are two first-generation students and one female student in the program.

\begin{tabular}{|l|l|l|l|l|l|l|l|l|l|l|}
\hline Program & \multicolumn{2}{l}{$\begin{array}{l}\text { Number of } \\
\text { Scholarships }\end{array}$} & \multicolumn{2}{l|}{ Male } & \multicolumn{2}{l|}{ Female } & \multicolumn{2}{l|}{$\begin{array}{l}\text { First } \\
\text { Generation } \\
\text { Student }\end{array}$} & $\begin{array}{l}\text { Non- } \\
\text { Traditional } \\
\text { Student }\end{array}$ \\
\hline & $\begin{array}{l}\text { Fall } \\
\text { 2015 }\end{array}$ & $\begin{array}{l}\text { Spring } \\
\mathbf{2 0 1 6}\end{array}$ & $\begin{array}{l}\text { Fall } \\
\mathbf{2 0 1 5}\end{array}$ & $\begin{array}{l}\text { Spring } \\
\mathbf{2 0 1 6}\end{array}$ & $\begin{array}{l}\text { Fall } \\
\mathbf{2 0 1 5}\end{array}$ & $\begin{array}{l}\text { Spring } \\
\mathbf{2 0 1 6}\end{array}$ & $\begin{array}{l}\text { Fall } \\
\mathbf{2 0 1 5}\end{array}$ & $\begin{array}{l}\text { Spring } \\
\mathbf{2 0 1 6}\end{array}$ & $\begin{array}{l}\text { Fall } \\
\mathbf{2 0 1 5}\end{array}$ & $\begin{array}{l}\text { Spring } \\
\mathbf{2 0 1 6}\end{array}$ \\
\hline $\begin{array}{l}\text { Computer } \\
\text { Engineering }\end{array}$ & $\mathbf{9}$ & $\mathbf{1 1}$ & $\mathbf{9}$ & $\mathbf{1 1}$ & $\mathbf{0}$ & $\mathbf{0}$ & $\mathbf{1}$ & $\mathbf{1}$ & $\mathbf{6}$ & $\mathbf{7}$ \\
\hline $\begin{array}{l}\text { Computer } \\
\text { Science }\end{array}$ & $\mathbf{4}$ & $\mathbf{3}$ & $\mathbf{3}$ & $\mathbf{2}$ & $\mathbf{1}$ & $\mathbf{1}$ & $\mathbf{1}$ & $\mathbf{1}$ & $\mathbf{1}$ & $\mathbf{1}$ \\
\hline Total & $\mathbf{1 3}$ & $\mathbf{1 4}$ & $\mathbf{1 2}$ & $\mathbf{1 3}$ & $\mathbf{1}$ & $\mathbf{1}$ & $\mathbf{2}$ & $\mathbf{2}$ & $\mathbf{7}$ & $\begin{array}{l}\mathbf{8} \\
(\mathbf{5 7 \%})\end{array}$ \\
\hline
\end{tabular}

Table 3: Number of Scholarships Awarded and the Demographics of Scholars

\section{Assessment}

Assessment and evaluation of the LEAP program at UVU will be an on-going process. The impact on students' progress, departments and disciplines will be assessed through quantitative (measureable) and qualitative (observation, interviewing) measures to see if progress is made toward achieving its goals. Table 4 gives an overview of the assessment and evaluation plan for the scholarship program ${ }^{6}$.

\begin{tabular}{|l|l|}
\hline \multicolumn{2}{|c|}{ Evaluation Plan } \\
\hline \multicolumn{1}{|c|}{ Targeted Outcomes } & \multicolumn{1}{c|}{ Measurement Tool } \\
\hline Objective 1: Increase support for financially needy, but academically qualified students in CS \& E. \\
\hline $\begin{array}{l}\text { An average of 21 students per year } \\
\text { will receive S-STEM scholarships }\end{array}$ & $\begin{array}{l}\text { Quantitative: The breakdown of scholarships should be } \\
\text { at least 14 in year 1, 23 in year 2, 26 in year 3, and 21 in } \\
\text { year 4. }\end{array}$ \\
\hline
\end{tabular}




\begin{tabular}{|c|c|}
\hline $\begin{array}{l}\text { and be admitted to the } L E A P \\
\text { program. }\end{array}$ & $\begin{array}{l}\text { Qualitative: Scholarship recipients include women, } \\
\text { minorities, and non-traditional students }\end{array}$ \\
\hline \multicolumn{2}{|c|}{ Objective 2: Increase the completion rates of participating students in CS \& E. } \\
\hline $\begin{array}{l}\text { Students in the LEAP program will } \\
\text { graduate or be accepted into 4-year } \\
\text { programs at a higher rate than their } \\
\text { peers in the targeted programs. }\end{array}$ & $\begin{array}{l}\text { Quantitative: IRI will report enrollment and graduation in } \\
\text { the targeted programs } \\
\text { Qualitative: Student participation in LEAP program } \\
\text { activities will be tracked to determine its value in } \\
\text { retaining students and increasing academic outcomes. }\end{array}$ \\
\hline \multicolumn{2}{|c|}{ Objective 3: Provide leadership training and opportunities for students. } \\
\hline $\begin{array}{l}\text { Students will develop a sense of } \\
\text { community and professional } \\
\text { confidence from participation in the } \\
\text { IEEE club, multidisciplinary projects, } \\
\text { and peer-to-peer mentoring. }\end{array}$ & $\begin{array}{l}\text { Quantitative: The project team will track the number of } \\
\text { leadership opportunities accepted by each student. } \\
\text { Qualitative: An annual participant survey will be used to } \\
\text { determine student's sense of community and } \\
\text { confidence; faculty mentors will evaluate students on } \\
\text { having achieved leadership goals. }\end{array}$ \\
\hline \multicolumn{2}{|c|}{ Objective 4: Strengthen interdisciplinary engaged learning opportunities for students. } \\
\hline $\begin{array}{l}\text { Students will apply key concepts } \\
\text { through multidisciplinary IEEE Club } \\
\text { projects and a capstone project. }\end{array}$ & $\begin{array}{l}\text { Quantitative: All students will participate in at least one } \\
\text { IEEE Club project each year and one capstone project. } \\
\text { Qualitative: Students are evaluated by the quality of their } \\
\text { work, a written report, and an oral presentation. }\end{array}$ \\
\hline \multicolumn{2}{|c|}{ Objective 5: Provide a trained faculty mentor to each program participant. } \\
\hline $\begin{array}{l}\text { Early and consistent interaction with } \\
\text { a faculty mentor will make the } \\
\text { transition to college smoother, } \\
\text { increase academic success, and } \\
\text { increase year-to-year persistence. }\end{array}$ & $\begin{array}{l}\text { Quantitative: Track the number of mentors, number of } \\
\text { mentor sessions, and faculty mentor training } \\
\text { attendance. } \\
\text { Qualitative: The annual participant survey will help } \\
\text { determine how effective students feel faculty mentoring } \\
\text { has been; student's annual reports \& faculty mentor } \\
\text { semester reports will be used. }\end{array}$ \\
\hline \multicolumn{2}{|c|}{ Objective 6: Establish mechanism for acquiring at scholarships to sustain the program. } \\
\hline $\begin{array}{l}\text { At least five full-tuition scholarships } \\
\text { will be obtained by the end of the } \\
\text { funding period and a plan to pursue } \\
\text { further funding will be created. }\end{array}$ & $\begin{array}{l}\text { Quantitative: Track the number and amount of } \\
\text { scholarship gifts obtained through Development \& } \\
\text { Alumni Relations. } \\
\text { Qualitative: The Project Evaluator and Development } \\
\text { Officer will determine that the plan to pursue continued } \\
\text { funding has merit. }\end{array}$ \\
\hline
\end{tabular}

Table 4: Evaluation Plan ${ }^{6}$

\section{Conclusion}

This paper is a presentation of an overview of the work and progress of UVU's LEAP program which is an NSF supported S-STEM project whose goal is to enable academically talented and financially needy students to pursue college degree in computer science and Engineering. This grant is a five year grant (one year planning and four years offering scholarship) which has gotten off to a good start in the first year and did well in the second year. Overall, the LEAP program is an effective tool in helping to recruit, retain, and promote computer science and computer engineering programs. 


\section{Acknowledgements}

This project is supported by the National Science Foundation through the S-STEM program, Award No. S-STEM 1356716. Any opinions, findings, and recommendations expressed in this paper are those of the authors and do not necessarily reflect the views of the National Science Foundation.

\section{Reference:}

1. Annual Report on the State of Poverty in Utah, 2012, Community Action Partnership of Utah.

2. Information and statistics provided by the UVU Office of Institutional Research and Information - IRI.

3. Utah Department of Workforce Services, "College to career: Projected job openings in occupations that typically require a bachelor's degree," Occupational Outlook Quarterly, Summer 2013.

4. Sutherland, John, Chair, Utah Technology Council, Budget Impacts on Engineering Education, 2012.

5. Utah Valley University Institution Research and Information web site, http://www.uvu.edu/iri/academicprograms/statistics.html, accessed 1-22-2016.

6. NSF Proposal document, "Strengthening Outcomes for Students in Computer Science and Engineering through Leadership, Engagement, Academic Mentoring, and Preparation (LEAP)", August 2013.

7. Kuh, G.D., "Organizational Culture and Student Persistence: Prospects and Puzzles", Journal of College Student Retention, 39(1), 23-39, 2002.

8. Kuh, G. D., et al, "Student Success in College: Creating Conditions that Matter", Jossey-Bass, 2005.

9. Laufgraben, J. L., "Learning Communities", Jossey-Bass, 2005.

10. Annual Report on the State of Poverty in Utah, 2014, Community Action Partnership of Utah, http://caputah.org/images/poverty-reports-full/2014_Annual_Report_on_Poverty_compressed_1.pdf , access on 3-14-2016.

11. U.S. Census Bureau, 2011, http://www.census.gov/popest/data/historical/2010s/vintage_2011/, accessed on 3-14-2016. 